\title{
THE IMPORTANCE OF ECONOMIC EDUCATION IN PRESCHOOL CHILDREN
}

\author{
Obid Muzrobovich Achilov
}

Lecturer At The Department Of Preschool Education, Denau Institute Of Entrepreneurship And Pedagogy, Uzbekistan

Mahliyo Norbutayevna Kochkinova

Student Of The Denau Institute Of Entrepreneurship And Pedagogy, Uzbekistan

Ozodaxon Muzaffar Qizi Kamolova

Student Of The Denau Institute Of Entrepreneurship And Pedagogy, Uzbekistan

\section{ABSTRACT}

This article discusses the specifics and important aspects of economic education of children in preschool education, as well as the content and priorities of comprehensive development, expanding the worldview of children through economic education. Along with the differences between economic education and all other types of education, there are comments on its interdependence and its role in child development.

KEYWORDS:- Cost, market economy, initiative, business, economic consciousness, culture, entrepreneurship, money, treatment, distribution, administration, command, waste, honesty, justice.

\section{INTRODUCTION}

At a time of transition to a market economy, it is especially important to cultivate economic thinking in young people. Today, the head of our state pays special attention to this issue in preschool education institutions. There are a lot of opportunities for entrepreneurship and production in our country, and in order to use these opportunities effectively, not only parents but also preschoolers need to have the above concepts. First of all, children need to have a perfect, complete understanding of economic education. Economic education is the development of children's ability to think about thrift, diligence, initiative, entrepreneurship, economic accounting, and at the same time. The content of economic education has been substantially enriched by Eastern thinkers. For example, Muhammad Ibn Musa Al-Khwarizmi emphasizes the importance of mathematics in human life. In his opinion, one should know the science of arithmetic and be mature in one's work. Then he can determine the results of his labor through measurements ${ }^{1}$.

The National Program of Personnel Training of

\footnotetext{
${ }^{1}$ Fotima Kadyrova, Shoista Toshpolatova, Nargiza Kayumova, Malohat Azamova Preschool pedagogy "Taffakkur" publishing house Tashkent 2019 page 205
} 
CURRENT RESEARCH JOURNAL OF PEDAGOGICS 2(6): 137-140, June

2021 DOI: https://doi.org/10.37547/pedagogics-crjp-02-06-26

ISSN 2767-3278

(C)2021 Master Journals

\section{Crossref do) 81 Google}

Accepted 25thJune, 2021 \& Published 30 th June, 2021

the Republic of Uzbekistan emphasizes the need to "improve the economic education and upbringing of students at all levels of education."

A well-rounded person must first receive economic education. Without economic education, without the skills and habits associated with it, it is impossible to be a truly perfect person. First of all, he must appreciate his own work and the work of others, and scientifically know the educational basis of its application in life. is built on the basis of education. Discipline, on the other hand, is reflected in the application of the above qualities in daily life. This problem is organized in a unique way in preschool children. Because it is not possible to combine economic knowledge, culture, consciousness, skills and habits in the children of the preparatory group at once. Therefore, it is an important task for the preschool group to initially form an understanding of the economy, understanding and skills related to their application in marriage.

The economic knowledge of preschool children, which is characteristic of a well-rounded person, is gradually organized in close connection with the increase of their age. Economic consciousness and culture are not formed at once. Children's imagination in this area needs to be developed directly in the classroom. This is the responsibility of the preschool educator. This work is also carried out in the pre-school period. It is no exaggeration to say that providing economic education to preschool children is one of the top priorities of the education and upbringing program in today's rapidly evolving world. "Our priority is economic change, the complete abandonment of the administrative command system of distribution and the formation of social relations based on a market economy, which is an expression of our resolute

${ }^{2}$ National Program of Personnel Training of the Republic of Uzbekistan, 1997 Aug 29 (page 45). approach to reforming society," said the First President I. Karimov.

The use of labor education in inculcating in the minds of children the basic concepts of economic education is based on the idea of forming students as independent thinkers.

Economic education of children begins with the family and continues in preschool. The content of economic education has received a great deal of attention from Eastern thinkers, the formation of rational needs, the ability to compare them with material opportunities, the education of children in the pursuit of their own needs.

As you know, the word "economy" has a wide and deep meaning. The word is often used interchangeably with the word "thrift." When it comes to saving, we know how to avoid waste. Abdullah Avloni, a well-known Uzbek thinker, defines the concept of "economy" as follows: "Economy is the knowledge of the value of goods such as money and goods.

Savings. Abu Nasr al-Farabi writes in his book On Achieving Happiness: "One should know how to spend one's money properly. Jealousy in spending money leads to greed. And the unplanned use of money leads to recklessness. It is obvious that Eastern thinkers have focused on the need to expand children's economic thinking in schools and families, to teach them to save, initiative, entrepreneurship, economic accounting on the basis of life experience ${ }^{3}$.

"O my son, do not be heedless of amassing wealth, but if you wish to do all things, strive to be honest and always be pleasing to you. If you have a lot of money, create it with appreciation and action. After all, a small amount of wealth created by destiny and action is better than a lot of wealth without destiny and action. If the goods are small, it is obligatory to keep them well, 
CURRENT RESEARCH JOURNAL OF PEDAGOGICS 2(6): 137-140, June

2021 DOI: https://doi.org/10.37547/pedagogics-crjp-02-06-26

ISSN 2767-3278

(C)2021 Master Journals

\section{Crossref do) 81 Google}

Accepted 25th June, 2021 \& Published 30 ${ }^{\text {th }}$ June, 2021

because not everyone can save a little, and not many. If you can afford it, set aside two pennies for the necessities of old age and infirmity, and never turn a blind eye to it. There is a hadith that has become ingrained in the minds of the people: "Those who work in the economy will not be poor," which can be explained as follows: He who can afford it can save himself from poverty, even if he is not rich. The good or bad of the economy is directly related to austerity. Therefore, it is necessary to educate the child about the importance of economics and income in the family. Children get this job directly at preschool age. Therefore, one of the important problems of the day is to pay special attention to the composition of the basics of basic economic concepts and skills in children ${ }^{4}$.

"Every business has a reason. But the cause of poverty is waste. ${ }^{\mathbf{5}}$ Waste is not only a waste of wealth, but also a waste of food, interests, and speech. Waste deceives the body, hurts the nafs, deprives the mind, and kills the living. " it means spending, or leaving nothing for oneself and one's children, to spend all one's trifles on trifles. Wastefulness is the development of the family, the state and society in accordance with the Constitution of the Republic of Uzbekistan and other normative acts. there should be no obstruction. Entrepreneurship, initiative, honesty, justice, the interests of the people and the state in this area will bring effective results. There are sources of economic education of preschool children, such as the media, theater, cinema, travel, exhibitions, without which it is difficult to solve the problem of economic culture, thinking, consciousness of citizens and their preparation for social life.

Fostering thrift in the family. Money also nurtures. This should not be ignored. Ignoring

\footnotetext{
${ }^{4}$ Al-adab al-mufrat. Imam Ismail al-Bukhari. Page 131.

${ }^{5}$ One hundred and one hadiths. T., "Labor," 1991, p.38.
}

money circulation often leads to a two-sided problem. The habit of selfishness and unwillingness to know the economic hardships of the family is nurtured. Second, money greed can nurture the desire to save money. From an early age, the child should be introduced to the household chores. The child must know the family budget, the "estimate" of family life for a month, a day. He must know the cost of basic foods - bread, butter, milk, meat, fish, vegetables, etc. As a child grows up, he should get acquainted with the value of things (clothes, shoes, TV, etc.). If the parent is working overtime, the child must understand that the mother and father are working to ensure that everyone in the family lives well. He must understand the logic: Everyone can do their best to improve family life. should contribute.

Decision-making of children's economic consciousness develops in them the formation of a system of economic concepts, their mastery of the laws of economic development of society, economics, general information about the organization of production, the development of thinking operations (analysis, synthesis, generalization, etc.). the simplest economic analysis involves building skills and competencies.

\section{REFERENCES}

1. National Program of Personnel Training of the Republic of Uzbekistan, 1997 August 29. Page 45.

2. One hundred and one hadiths. T., "Labor," 1991, p.38.

3. Al-adab al-mufrat. Imam Ismail al-Bukhari. Page 131.

4. Nightmare. Pp. 70-72.

5. Fotima Kadyrova, Shoista Toshpolatova, Nargiza Kayumova, Malohat Azamova Preschool pedagogy publishing house 
CURRENT RESEARCH JOURNAL OF PEDAGOGICS 2(6): 137-140, June

2021 DOI: https://doi.org/10.37547/pedagogics-crjp-02-06-26

ISSN 2767-3278

(C)2021 Master Journals

Crossref doi 81 Google

Accepted 25thJune, $2021 \&$ Published 30 ${ }^{\text {th }}$ June, 2021

"Taffakkur" Tashkent 2019, page 205 